\title{
Effect of Pressure Levels on Risk Levels of Deviant Behavior of Correctional Prisoners
}

\author{
Rangga Wahyu Dhika ${ }^{1^{*}}$ \\ ${ }^{1}$ Prodi Teknik Pemasyarakatan, Politeknik Ilmu Pemasyarakatan, Depok, Jawa Barat, Indonesia \\ *Corresponding author, e-mail: ranggawahyudika@gmail.com
}

Received 2020-03-13; Revised 2020-03-17; Accepted 2020-05-02; Published Online 2020-05-30

\section{Conflict of Interest} Disclosures:

The authors declare that they have no significant competing financial, professional or personal interests that might have influenced the performance or presentation of the work described in this manuscript.

\section{(c) (i) \\ This is an open access article distributed under the Creative Commons 4.0 Attribution License, which permits unrestricted use, distribution, and reproduction in any medium, provided the original work is properly cited. $\odot 2017$ by author}

\begin{abstract}
The results of recentt study abaout mental health disorders status showed that $36 \%$ experienced mental health disorders in the form of anxiety and women, the incidence rate was higher than men, $61 \%$ : 39\%. The study was conducted 62 surveys in 12 countries covering 22,790 correctional prison residents found that every 6 months there was a prevalence of psychosis in men $3.7 \%$ and women $4 \%$ major depression in men $10 \%$ and women $12 \%$ and personality disorders in men $65 \%$ men and $42 \%$ women. From these data, many Penitentiary Citizens experience mental health disorders such as stress and sexual deviations. Deviations committed by Penitentiary Members include such as hallucinating / fantasizing, masturbating, and biological violation activities carried out by men and women in Correctional Institutions. This study uses the General Strain Theory theory by Robert Agnew using a quantitative approach. The data collected uses primary data in the form of distributing questionnaires to a predetermined sample of Penitentiary Guards. From the results of the study above the level of risk of deviant behavior of Correctional Guidance Citizens continues to increase along with the increasing level of pressure experienced by Correctional Guidance Citizens.
\end{abstract}

Keywords: Deviant Behavior, Correctional Prisoners and Health Disorders

How to Cite: R., W., Dhika. (2020). Effect of Pressure Levels on Risk Levels of Deviant Behavior of Correctional Prisoners. BISMA, VV (N): pp. 7-15, DOI: http://dx.doi.org/10.23887/bisma.v3i1 


\section{Introduction}

Stressor is an event that demands / requests an action from an individual. Not everyone is able to adapt and cope with the stressor, so that complaints arise that is stress (Wijaya, 2015). An acute stress reaction is a temporary disorder that exists in individuals without any other mental disorder (Safitri, 2017).

Table 1. Results of Mental Health Disorders Research from University of South Wales

\begin{tabular}{lll}
\hline Type of Disruption & Men & Women \\
\hline Anxiety & $61 \%$ & $39 \%$ \\
Personality Disorders & $65 \%$ & $42 \%$
\end{tabular}

$$
\text { Source : (Wijaya, 2015) }
$$

In the Kukuh thesis (Wijaya, 2015) containing research conducted by the University of South Wales shows that $36 \%$ experienced mental health disorders in the form of anxiety and women the incidence rate was higher than that of men which was $61 \%: 39 \%$. The study was conducted 62 surveys in 12 countries covering 22,790 correctional prisoners found that every 6 months there was a prevalence of psychosis in men $3.7 \%$ and women $4 \%$ major depression in men $10 \%$ and women $12 \%$ and personality disorders in men $65 \%$ men and $42 \%$ women.

Table 2. Residents of Class IIA Prison Correctional Facilities Jember

\begin{tabular}{ll}
\hline Type Of Stress & Total \\
\hline Normal Stress & $9,2 \%$ \\
\hline mild stress & $13,2 \%$ \\
moderate stress & $32,9 \%$ \\
\hline Severe stress & $43,3 \%$ \\
\hline
\end{tabular}

$$
\text { Source : (Wijaya, 2015) }
$$

According to Sweeney and Macfarlin explained "the term stres is easier to experience than it is to plain to define. We say this because we've all felt pressure, demains and strains that seems to go hand-in-hand without job. So, at a personal level we all what stres is" Based on this definition explains that stress is defined as pressure, tension and interference from a person's external environment (Edy Susanto, 2019). In the Kukuh thesis (Wijaya, 2015) research conducted by Anggraini in Jember Class IIA prison, in 76 people experiencing severe stress totaling 33 people (43.3\%), 25 people $(32.9 \%)$ experienced moderate stress, 10 people ( $13.2 \%)$ experienced mild stress, seven people (9.2\%) experienced normal stress, and one person (1.3\%) experienced stress. In the journal Eko Aprianto (E. A. Ariyanto, 2016) entitled Stress Levels in Adolescents in LPKA Blitar, the study produced the types of reactions due to stress experienced by adolescents in LPKA Blitar are as follows in table 3.

Table 3. Types of Stress Reactions Experienced by Adolescents in LPKA Blitar

\begin{tabular}{cl}
\hline $\begin{array}{c}\text { Symptoms } \\
\text { Physical }\end{array}$ & $\begin{array}{c}\text { Pain that is felt } \\
\text { Back pain, neck and leg pain, dizziness, body aches, body weakness, lethargy }\end{array}$ \\
Cognitive & $\begin{array}{l}\text { Many thoughts, confused, old people's minds, insomnia, daydreaming, bored, } \\
\text { bored }\end{array}$ \\
Behavior & Lazy doing something, uncomfortable \\
Emotions & Sad, homesick, frightened, restless, hopeless \\
\hline
\end{tabular}

Source : (E. A. Ariyanto, 2016) 
Anxiety is also a great force in driving behavior, both deviant or disturbed behavior Behavior of fostered citizens who have different behaviors in general (Ratnawati \& Astari, 2019). Behaviors that appear due to stress include irritability, irritability with other fostered residents, stressful fostered residents also have an impact on their difficult sleep. Stress is a situation or stimulus where the welfare state of the individual is threatened. The stress response takes the form of an interactive mechanism that starts from the arrival of the stressor to the emergence of the stress response. This often happens to humans in conditions that are unpleasant and pressing conditions. The incident that often occurs is that humans can not overcome these problems and stress occurs. According to Lumongga (Duri Kartika, 2015) stress can be divided into two types namely distress and eustress.

Deviant behavior is interpreted as a person's behavior, actions, or responses to the environment that are contrary to the norms and laws that exist in society (Reynolds \& Harris, 2009). Social deviance is behavior that is not in accordance with the value of decency, both from the point of view of humanity (religion) as an individual and its justification. As part of social beings (Surya, 2003). Deviant behavior is deviation from the path of truth or something that cannot be accepted by society. Deviant behavior or social deviance is a form of behavior that is not in accordance with existing social norms (Rochaniningsih, 2014). Secondary deviations are deviant behavior that can not get tolerance from the community and is done repeatedly such as stealing, cheating, using narcotics, and others (Su'ud, 2011). Research conducted from the Center for Policy Research and Development at the Department of Law and Human Rights resulted in sexual deviant behavior found in the Class IIA Prison in Mataram (Febrian, 2019).

Table 4. Sexual Deviant Behavior Lapas IIA Mataram

\begin{tabular}{ccc}
\hline No & The deviant account & Sex behavior disorder \\
1 & 244 & Berhalusinasi/Berfantasi \\
2 & 171 & Masturbasi \\
3 & 169 & Aktifitas Pelanggaran Biologis \\
\hline Source : ( Febrian, 2019)
\end{tabular}

The research from the Center for Policy Research and Development at the Department of Law and Human Rights resulted in sexual deviant behavior found in the Class IIA Prison in Mataram. This fact is the result of research aimed at 326 Penitentiary Guides, 108 respondents consisting of the Head of Prison, Head of fostering, Head of Kamtib, Kasi Binadik, KPLP and guardians of Penitentiary Prisoners, as well as 22 communities including Penitentiary Guidance Families. As a result, 81 percent or 264 Penitentiary Citizens said they felt uncomfortable when their biological needs were not met. As many as 78 percent or 244 correctional prisoners often hallucinate or fantasize, 171 correctional prisoners or 57 percent masturbate and 52 percent or 169 correctional prisoners engage in biological activities in violation of the provisions. From the data above shows that stress can cause things that make Penitentiary Citizens do deviant behavior even deviant behavior can cause someone to lose their lives. Therefore, it is very important to know what causes the Correctional Prisoners feel stressed so that coaching can be done for prevent correctional prisoners from feeling stressed. This needs to be done to reduce the level of risk of deviant behavior by Penitentiary Guides. Based on the above background, we are interested in conducting a study entitled "Effect of Pressure Levels on Risk Levels of Deviant Behavior of Prisoners"

\section{Method}

This research is a quantitative study, which is a process of finding knowledge using data in the form of numbers as a means of analyzing information about some information (Herdiana, 2013). Quantitative research usually uses structured formats such as mathematics and statistics. By choosing this approach the data obtained in the form of the level of pressure experienced by Correctional Prisoners and the risk of deviant behavior of Correctional Prisoners. The purpose of this research is to describe and develop knowledge in a person in prison inmates who perform deviant behavior related to the level of pressure experienced by prison inmates. The benefit of this research is to find out the level of pressure experienced by Correctional Prisoners and its influence on the risk of deviant behavior of Correctional Prisoners. This 
research is expected to be able to broaden the horizons of cadets and can be used as an evaluation of a coaching program in order to minimize deviant behavior by Penitentiary Guides. At the data collection stage the researchers conducted primary data collection. Data collection was carried out by distributing questionnaires to 127 correctional prisoners selected as samples. The population is all data that is the center of attention of a researcher within the specified scope and time period. Population is a group of objects that have the same characteristics and are in the same place. This study uses all Penitentiary Citizens in country jail as the study population.

\section{Results and Discussion}

This study uses the General Strain Theory by Robert Agnew using a quantitative approach. The sample of this research is 127 correctional prisoners selected randomly. In this study using the following hypotheses:

Ho: The pressure experienced by Penitentiary Citizens does not affect the risk of deviant behavior.

Ha: Pressure experienced by Penitentiary Citizens influences the risk of deviant behavior.

The analys show that the asump Value Sig. (2-tailes) in the table above shows the value 0,000. With a significance level $\alpha=0.05$, it is obtained the decision to accept $\mathrm{H} 1$ because $0.05>0,000$. In other words, with a significance level of $5 \%$, there is sufficient evidence to state that the pressure experienced by Penitentiary Citizens influences the risk of deviant behavior. The data as show in tabel 5.

Table 5. Cross Tabulation

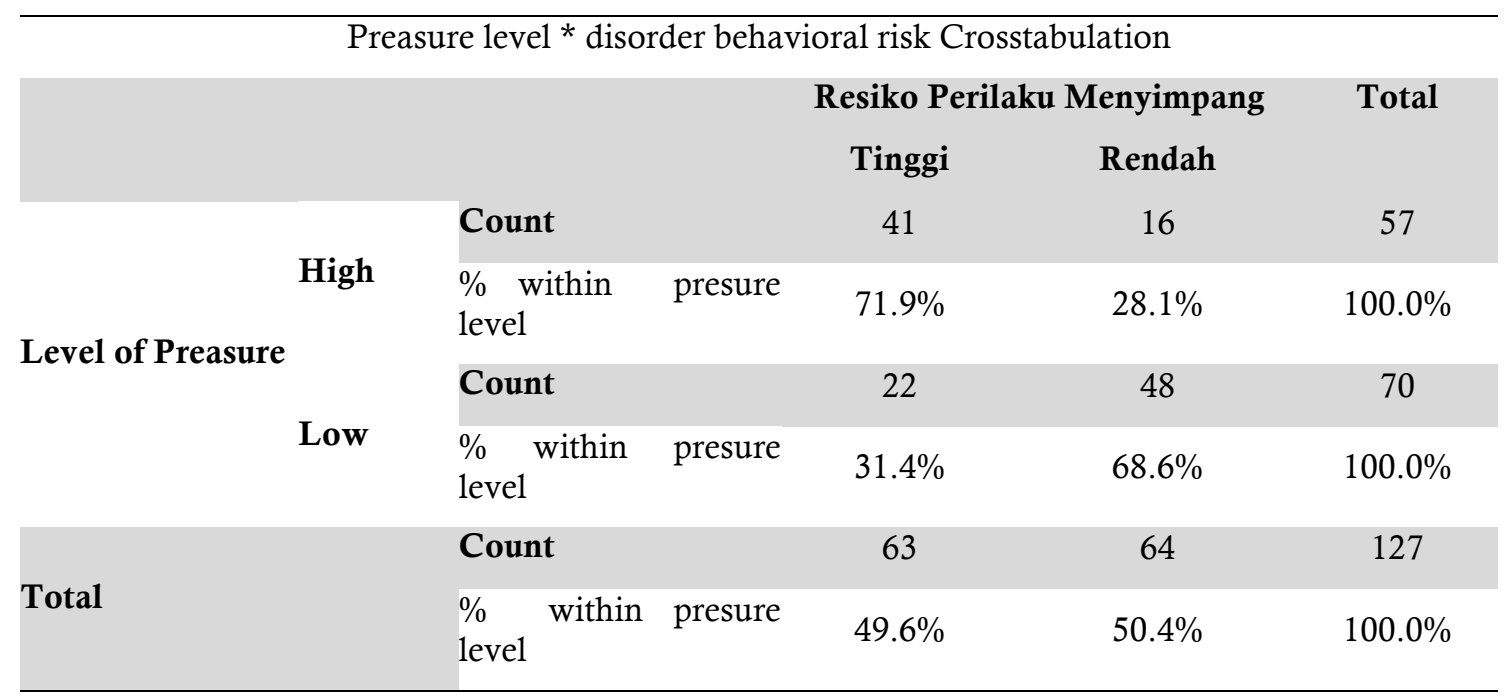

Source : Primary Data SPSS

The variable level of risk of deviant behavior of the majority correctional Prisoners comes from the variable pressure level experienced by the Correctional Prisoners high at $71 \%$, while the low is at $31.4 \%$. For the variable risk level of deviant behavior, the majority of correctional inmates are from the low pressure level experienced by correctional residents, which is $68.6 \%$, while the high is $28.1 \%$.

So that it can be concluded that the higher the pressure experienced by the Prisoners in Correctional Institution will lead to the tendency of risk behaviors to deviate Correctional Prisoners also increase. From the hypothesis below, the correlations test is as follows:

Ho: There is no relationship or correlation between the pressure experienced by Penitentiary Citizens to the risk level of deviant behavior of Penitentiary Prisoners

Ha: There is a relationship or correlation between the pressure experienced by Correctional Community Prisoners towards the risk of deviant behavior level of Correctional Prisoners. 
Tabel 6. Correlations

\begin{tabular}{llcc} 
& & Vartotiv & Vartotdv \\
Partotiv & Sig. (2-tailed) & 1 &, $540^{* *}$ \\
& $\mathrm{~N}$ & 127 &, 000 \\
& Pearson Correlation &, $540^{* *}$ & 127 \\
Vartotdv & Sig. (2-tailed) &, 000 & 127 \\
& $\mathrm{~N}$ & 127 & \\
$* *$. Correlation & is significant at the 0.01 level (2-tailed). & \\
\hline Source : Primary & &
\end{tabular}

Source : Primary Data SPSS

As the tabel 6, from the Sig (2-tailed) $=0,000<0.005$, it is found that Ho's decision is rejected and Ha is accepted. Therefore, it is concluded that with a significance level of $5 \%$, there is sufficient evidence that there is a relationship or correlation between the pressure experienced by Correctional Prisoners towards the level of risk of deviant behavior of Correctional Prisoners. The correlation strength of both the independent and dependent variables is $54 \%$, this shows the relationship between the independent and dependent variables is "sufficient". A positive correlation value indicates that the relationship between the two variables is unidirectional, as the level of pressure experienced by Correctional Prisoners increases, the level of behavioral risk deviate also deviate and vice versa.

Tabel 7. Variables Entered/Removed ${ }^{a}$

\begin{tabular}{|c|c|c|c|}
\hline Model & Variables Entered & Variables Removed & Method \\
\hline 1 & $\begin{array}{c}\text { Tingkat Tekanan yang Dialami } \\
\text { WBP }\end{array}$ & $\cdot$ & Enter \\
\hline \multicolumn{4}{|c|}{ a. Dependent Variable: Tingkat Resiko Perilaku Menyimpang WBP } \\
\hline b. All requested & entered. & & \\
\hline
\end{tabular}

In this study a regression will be conducted with the independent variable the level of risk behavior in deviant prisoners and the dependent variable the level of pressure experienced by the prisoners. From the table above it can be seen that the correlation value of the two variables is equal to $54 \%$ with a coefficient of determination of $29 \%$. So it can be said that the variable pressure level experienced by Correctional Guidance Citizens can explain the variable level of risk of deviant behavior of Citizens Correctional Development of $29 \%$.

Before conducting a regression analysis, it is necessary to test whether the regression equation can be made or not with the hypothesis below:

Tabel 8. Model Summary

\begin{tabular}{ccccc}
\hline Model & R & R Square & Adjusted R Square & Std. Error of the Estimate \\
1 &, $540^{\mathrm{a}}$ &, 291 &, 285 & 9,074
\end{tabular}

a. Predictors: (Constant), Tingkat Tekanan yang Dialami WBP 
Ho: Regression equations cannot be made

Ha: Regression equations can be made From the table above obtained a significance value of 0,000

So that it can be decided that the significance of alpha $<0.005$ then Ho is rejected. With a significance level of $5 \%$, there is enough evidence to state that the regression equation for the two variables can be made using the regression model below:

$$
\mathbf{Y}=\mathbf{a}+\mathbf{b x}
$$

Information :

Y: The level of risk of deviant behavior of Penitentiary Guards

$\mathrm{X}$ : The level of pressure experienced by Penitentiary Citizens

Tabel 9. Uji Coefficients ${ }^{a}$

\begin{tabular}{|c|c|c|c|c|c|c|}
\hline & \multirow[t]{2}{*}{ Model } & \multicolumn{2}{|c|}{ Unstandardized Coefficients } & \multirow{2}{*}{$\begin{array}{c}\text { Standardized } \\
\text { Coefficients } \\
\text { Beta }\end{array}$} & \multirow[t]{2}{*}{$\mathbf{T}$} & \multirow[t]{2}{*}{ Sig. } \\
\hline & & B & Std. Error & & & \\
\hline \multirow{2}{*}{1} & (Constant) & 71,320 & 11,024 & & 6,469 & ,000 \\
\hline & Vartotiv & ,533 & ,074 & , 540 & 7,165 & ,000 \\
\hline
\end{tabular}

a. Dependent Variable: Vartotdv

From the table above we get the following regression equation:

$$
Y=71,320+0.533(X)
$$

Interpretation: When the level of pressure experienced by Correctional Community Prisoners is constant, the level of risk of deviant behavior of Correctional Prisoners is 71.32. When the level of pressure experienced by prisoners in prison increases by one unit, the level of risk of misbehavior in prison inmates will increase by 0.533 .

Tabel 10. ANOVA ${ }^{\mathrm{a}}$

\begin{tabular}{rlccccc}
\hline & Model & Sum of Squares & df & Mean Square & F & Sig. \\
\cline { 3 - 4 } & Regression & 4226,520 & 1 & 4226,520 & 51,331 &, $000^{\mathrm{b}}$ \\
\hline & Residual & 10292,346 & 125 & 82,339 & & \\
& Total & 14518,866 & 126 & & &
\end{tabular}

a. Dependent Variable: Tingkat Resiko Perilaku Menyimpang WBP

b. Predictors: (Constant), Tingkat Tekanan yang Dialami WBP

Source : Primary Data SPSS

From the results of the study above the level of risk of deviant behavior of Correctional Guidance Citizens continues to increase along with the increasing level of pressure experienced by Correctional 
Guidance Citizens. So it can be concluded the relationship of the two variables is unidirectional. When the level of pressure experienced by Penitentiary Citizens increases, the level of risk behavior of deviant Penitentiary Prisoners also increases, and vice versa.

In this study using the General Strain Theory by Robert Agnew provides an explanation of crime and delinquency (Agnew \& Brezina, 2019). This theory focuses on three main types of tension. First, tension occurs when someone is unable to achieve the goals they want in a way that is in accordance with existing norms. Second, tension occurs when people lose something that is considered valuable to them, such as property or relationships between individuals. Third, tension occurs when someone is given a negative impulse such as verbal insults and physical attacks that cause a person to feel angry, frustrated, depressed, etc. Negative feelings that arise due to tension creates pressure that will encourage someone to commit delinquency or crime.

A Penitentiary Guided Society experiences many changes in his life when he has to live in a study. According to Gresham M. Sykes, the changes include Loss of Dignity, Loss of autonomy, Loss of liberty, Loss of security, Loss of goods and services, Loss of heterosexual realtionship, Loss of the coming future, Loss of profit \& Loss of the functioning member (Parkes, 2011). All forms of loss cause pressure on the Prison Assistance Citizens. This is in line with the General Strain Theory which states that the strain develops from the inability of someone to achieve a goal that is considered positive in society and in people. Robert Agnew stated with General Strain Theory the pressure that occurs on someone will cause frustration that can lead to delinquency or crime. Frustration is a form of negative emotions that should be resolved immediately. If this condition cannot be resolved properly, it will continue to be deviant behavior that is not in accordance with existing norms and other emotional problems. In the condition of correctional prisoners the deviant behavior is reflected by the behavior of prison correctional residents who are not in accordance with the existing regulations in correctional institutions or also called deviant behavior of prison inmates.

The above theory is in line with the results obtained in this study. From the correlation analysis conducted for pressure level variables experienced by correctional prisoners to the risk level of deviant behavior of correctional prisoners, the correlation results were $54 \%$. This means that the independent variable and the dependent variable have sufficient correlation.

In addition, the relationship between variables was also analyzed using a regression analysis that obtained an R-squared value of $29 \%$, so it can be concluded that the pressure level variable experienced by prison inmates can explain the variable level of risk of deviant behavior of prisoners. The regression equation obtained also shows that the two independent and dependent variables have a direct relationship. So the conclusion of this study is the level of pressure experienced by someone will pose a risk of deviant behavior from that person.

This results study is one of inportan information about how deviant behavioral construct by som environmantal and psychological factors. The deviant are one form of destructive behavior. This behavior is inpact by inmoral and emosion disorder. Enhancing resiliensi is one effort to preventing the deviant behavior. The society counselor could be inprove the resilient by use some counseling methode, such as cognitive behavioral (CBT), Rational emotife behavioral (REBT) and so son (Suranata, Atmoko, \& Hidayah, 2017).

\section{Conclusion}

The results of the study show the level of risk of deviant behavior of Correctional Guidance Citizens continues to increase along with the increasing level of pressure experienced by Correctional Guidance Citizens. So it can be concluded the relationship of the two variables is unidirectional. When the level of pressure experienced by Penitentiary Citizens increases, the level of risk behavior of deviant Penitentiary Prisoners also increases, and vice versa. This study uses a theory from Robert Agnew namely General Strain Theory which focuses on three main types of strains. First, tension occurs when people cannot reach their goals in the right way. Second, tension occurs when people lose something of value to them. Third, tension occurs when people are encouraged to do negative things. The three tensions above encourage a person to commit various forms of social deviation such as delinquency which is considered to be a method to reduce the tension that arises. If related to the title of the research, this pressure will likely be experienced 
by fostered citizens and can lead to the risk of deviant behavior related to the author's research, namely due to the pressure caused by the tension that occurs in correctional fostered citizens while in prison and will pose a risk of deviant behavior of fostered citizens correctional facilities.

\section{References}

Agnew, R., \& Brezina, T. (2019). General strain theory. In Handbook on crime and deviance (pp. 145-160). Springer, Cham.

Ariyanto, E. A. (2016). Tingkat Stress pada Narapidana Di Lapas Blitar. Jurnal Psikologi Indonesia, 5(3), $226-231$.

Duri Kartika, C. (2015). Hubungan antara kecerdasan emosi dengan stres akademik mahasiswa [Universitas Muhammadiyah Surakarta]. http://eprints.ums.ac.id/37501/6/BAB II.pdf

Edy Susanto, M. (2019). Stress Kerja. Journal of Chemical Information and Modeling, 53(9), 1689-1699. https://doi.org/10.1017/CBO9781107415324.004

Febrian, M. R. (2019). Analisis implementasi penyelenggaraan promosi kesehatan rumah saki di RS Bhineka bakti husada tahun 2019 (Doctoral dissertation, Universitas Pembangunan Nasional Veteran Jakarta).

Herdiana. (2013). Hubungan Antara Keterampilan Berpidato dengan Prestasi Belajar PAI di SMP YPP Nurul Huda Surabaya. Journal of Chemical Information and Modeling, 53(9), 1689-1699.

Parkes, R. (2011). Hard times: Is the "rehabilitation revolution" bad news for enrichment activities with prisoners? British Journal of Community Justice, 9(2), 125-139.

Ratnawati, D., \& Astari, I. D. (2019). Hubungan Tingkat Stres Dengan Perilaku Berpacaran Pada Remaja Di SMA X Cawang Jakarta Timur. Jurnal Profesi Medika : Jurnal Kedokteran Dan Kesehatan, 13(1). https://doi.org/10.33533/jpm.v13i1.908

Reynolds, K. L., \& Harris, L. C. (2009). Dysfunctional customer behavior severity: An empirical examination. Journal of retailing, 85(3), 321-335.

Rochaniningsih, N. S. (2014). Dampak Pergeseran Peran Dan Fungsi Keluarga Pada Perilaku Menyimpang Remaja. Jurnal Pembangunan Pendidikan: Fondasi Dan Aplikasi, 2(1). https://doi.org/10.21831/jppfa.v2i1.2618.

Safitri, T. (2017). Strategi coping pada ibu muda yang mengalami stres pernikahan [Universitas Islam Negeri Sunan Ampel Surabaya]. http://digilib.uinsby.ac.id/15841.

Suranata, K., Atmoko, A., \& Hidayah, N. (2017, August). Enhancing Students' Resilience: Comparing The Effect of Cognitive-Behavior And Strengths-Based Counseling. In 2nd International Conference on Innovative Research Across Disciplines (ICIRAD 2017). Atlantis Press

Su'ud, S. (2011). Remaja dan perilaku menyimpang. Perilaku Menyimpang, 1(2), 34-43.

Surya, M. (2004). Psikologi pembelajaran dan pengajaran. Bandung: Pustaka Bani Quraisy, 73-4.

Wijaya, K. A. (2015). Hubungan antara Dukungan Keluarga dengan Tingkat Stress Narapidana di Lembaga Pemasyarakatan Kelas IIA Kabupaten Jember. 
financial, professional or personal interests that might have influenced the performance or presentation of the work described in this manuscript.

Copyrights Holder: $<$ Dhika $><2020>$

https://doi.org/10.xxxx/Xxxxx

Open Access Article | CC-BY Creative Commons Attribution 4.0 International License.

Word Count: 3552
First Publication Right: BISMA The Journal of Counseling 